\title{
PRINCIPLES OF CROP MODELING AND SIMULATION: I. USES OF MATHEMATICAL MODELS IN AGRICULTURAL SCIENCE
}

\author{
D. DOURADO-NETO ${ }^{1,6}$; D. A. TERUEL ${ }^{1,7}$; K. REICHARDT ${ }^{2,5,6}$; D.R. NIELSEN ${ }^{3}$; J. A. FRIZZONE ${ }^{4,6}$; \\ O.O.S. BACCHI ${ }^{5,6}$ \\ ${ }^{1}$ Depto. de Agricultura-ESALQ/USP, C.P. 9, CEP: 13418-900 - Piracicaba, SP, Brasil. \\ ${ }^{2}$ Depto. de Física e Meteorologia-ESALQ/USP, C.P. 9, CEP: 13418-900 - Piracicaba, SP, Brasil. \\ ${ }^{3}$ Dept. of Land, Air and Water Resources, University of California, Davis, USA. \\ ${ }_{5}^{4}$ Depto. de Engenharia Rural-ESALQ/USP, C.P. 9, CEP: 13418-900, Piracicaba, SP, Brasil. \\ ${ }^{5}$ Centro de Energia Nuclear na Agricultura/USP, C.P. 96, CEP: 13400-970 - Piracicaba, SP, Brasil. \\ ${ }^{6}$ Bolsista do $\mathrm{CNPq}$ \\ ${ }^{7}$ Bolsista da FAPESP
}

\begin{abstract}
Modeling techniques applied to agriculture can be useful to define research priorities and understanding the basic interactions of the soil-plant-atmosphere system. Using a model to estimate the importance and the effect of certain parameters, a researcher can notice which factors can be most useful. The modeler should define his objectives before beginning his work and construct a model that fulfills the proposed objectives.

Key Words: crop modeling, simulation
\end{abstract}

\section{PRINCÍPIOS DE MODELAGEM E SIMULAÇÃO: I. USO DE MODELOS MATEMÁTICOS EM AGRICULTURA}

RESUMO: A técnica de modelagem em agricultura pode ser útil para definir as prioridades de pesquisa, bem como para melhor entender as interações que ocorrem no sistema solo-planta-atmosfera. O modelo pode ser utilizado para estimar a importância e o efeito de certos parâmetros no intuito de definir os fatores a serem considerados. O modelador deve definir seus objetivos antes de iniciar o trabalho experimental, bem como desenvolver um modelo que atenda o objetivo proposto.

Descritores: modelagem em agricultura, simulação

\section{INTRODUCTION}

As agriculture becomes more intensive, the demand for a higher level of control of the environment in which the plants grow increases. This control ranges from better strategies of soil management to "closed" environments, where most, if not all, the atmospheric and soil variables can be adjusted. Based on this premise, plant growth and development models should be elaborated to supply a basis for planning and managing crop production.

Crop modeling can also be useful as a means to help the scientist define research priorities. Using a model to estimate the importance and the effect of certain parameters, a researcher can observe which factors should be more studied in future research, thus increasing the understanding of the system. The model has also the potential of helping to understand the basic interactions in the soil-plant-atmosphere system.

\section{CROP MODELING AND SIMULATION}

To simulate means to imitate, to reproduce, to appear similar. (Pereira, 1987). The art of simulating is as old as man. From the origin of the civilization, man had to struggle to survive, using, even if unconsciously, simulations of real future processes to be ready for life.

Simulation is, therefore, an analogy with the reality, being common in many areas. An athlete simulates during training the conditions that will prevail in the real competition; students make exercises and exams simulating their future work; pilots 
simulate on earth several flight conditions through the use of prototypes.

In agriculture, the simulation is important to forecast the results of a certain system management or of a certain environmental condition (Wu et al., 1996).

Model is a word that admits several connotations, among which the following can be mentioned: (i) the representation of some entity, usually in smaller size than the original; (ii) a simple description of a system, used to explain it or to perform calculations (Crowther, 1995; Procter, 1995).

It can be noticed, based on the above definitions, that models can be a prototype, a simplified representation, as well as an abstraction of a reality (system).

\section{THE CLASSIFICATION OF MODELS}

Models can be classified in different types: conceptual, physical or mathematical (Acock \& Acock, 1991).

All of us have our own concepts of how the world works and why certain things happen, every hypothesis that is tested has a conceptual model supporting it. Physical down-scaled representations (physical models) of the system have been used by engineers for a long time, but they are rarely used to represent biological systems, although it can be said that a plant in an experimental plot or container is a physical model of the crop in the field.

When the behavior of a system is described mathematically, through equations, that representation of the system is a mathematical model. The mathematical model represents quantitatively assumed hypotheses about the real system, allowing one to deduce its consequences. They have gradually become more popular, yet more sophisticated, because personal computers have become more accessible. They can be classified in a number of classes, but the two main ones are the empirical, and the mechanistic models (Acock \& Acock, 1991).

The empirical models, sometimes called correlative or statistical models, describe relationships among variables without referring to the correlated processes.

The mechanistic models (models at the level of processes or simulators), also called explanatory models, try to represent cause-effect relationships among the variables.

While a mechanistic model of vegetative growth describes the plant performance based on the knowledge of the processes that are taking place in its growth and development, an empirical model describes the plant behavior based directly on observations at the plant level.

It should be clear that, at certain organization level, all models are empiric. A model that simulates crop yield can be mechanistic at one level, if it represents the relations between all plant processes, but it will sure be empirical at some lower level, such as the variation in gross photosynthetic rate according to the temperature.

An empirical model at the prediction level can be found in Waggoner (1984), in which wheat yield in a given year and place is calculated in function of meteorological variables, such as temperature, precipitation and number of days warmer than $32^{\circ} \mathrm{C}$, in a simple equation, without representing the plant processes, by just varying the constants of the equation (weights of each variable) according to the location.

An empirical model at the organ level can be found in Teruel (1995), in which the sugar-cane leaf area index is calculated by an exponential-potential equation, the only variable being the Growing Degree Days (GDD) accumulated from planting, varying the constants in function of the cultivation cycle:

$$
L A I_{n}=\left(\sum_{i=1}^{n} G D D_{i}\right)^{b} e^{a+c \cdot \sum_{i=1}^{n} G D D_{1}}
$$

where LAI refers to the leaf area index, GDD to degree-days ( ${ }^{\circ} \mathrm{C}$.day), and $a, b$ and $c$ are the fitting constants.

Two classic ways of calculating the decrease in yield in function of water stress are empiric equations:

(i) Jensen (1968):

$$
\frac{Y a}{Y m}=\sum_{\mathrm{i}=1}^{\mathrm{n}}\left(\frac{\mathrm{ETa}_{\mathrm{i}}}{\mathrm{ETm}_{\mathrm{i}}}\right)^{\lambda}
$$

in which: $\mathrm{Ya} / \mathrm{Ym}$ is the relationship between the actual yield and a possible maximum, for the location and chosen crop; $\mathrm{ETa}_{\mathrm{i}} / \mathrm{ETm}_{\mathrm{i}}$ is the relationship between the actual evapotranspiration and that occurred without water restrictions in the stage $i ; 1_{i}$ the relative sensitivity coefficient of the crop for water stress during the stage i; and (ii) Stewart et al. (1977): 


$$
1-\frac{Y a}{Y_{m}}=\beta\left(1-\frac{\mathrm{ETa}}{\mathrm{ETm}}\right)
$$

in which $\mathrm{ETa} / \mathrm{ETm}$ is the relationship between the actual evapotranspiration and that occurred without water restrictions for the complete cycle of the crop and $\beta$ the crop sensitivity constant for water stress.

One problem with these models, already empirical at the forecast level, is that they cannot be extrapolated. They must only be used in conditions similar to those in which they were generated.

In contrast, mechanistic models try to represent processes in the system up to two organization levels below the forecast level. A mechanistic model to forecast crop yield will represent the processes at organ level, like photosynthesis, respiration, and foliar expansion and abscission, only being empirical down to this level.

The software GLYCIM (Acock et al., 1985) is an example of a mechanistic model to predict the soybean growth and yield. It consists of thousands of equations describing the atmospheric and soil environments, light interception by the leaves, photosynthesis, carbon partition between different organs, respiration, and water and nutrient uptake.

At the photosynthesis organization level, for example, the model stops being mechanistic and becomes empirical, because the equation that represents the photosynthesis for leaf area does not represent a correlation between variables.

One is still learning how to develop and create mechanistic models and, nowadays, the empirical models at the forecast level are still the most popular. However, the mechanistic models have a much larger potential to allow extrapolation in the forecasts outside the boundaries in which they were generated (Chanter, 1981). Their superiority as simulation models is gradually being recognized.

\section{AGRICULTURAL SCIENCE: USES OF MATHEMATICAL MODELS}

According to Rimmington \& CharlesEdwards (1987), three types of research activities can be defined in the agricultural sciences: (i) the acquisition of knowledge; (ii) the ordering of knowledge and the development of understanding on that knowledge, and (iii) the application of the knowledge and/or understanding to the solution of practical problems.

Mathematical models can be used in different ways within each one of these three activities. At this point it is important to differentiate understanding from knowledge.

To know is simply to be conscious of the facts regarding a phenomenon, whereas to understand is to perceive the significance of a phenomenon or to be able to explain it based on the knowledge of it (Rimmington \& Charles-Edwards, 1987).

Mathematical models are basically a simplified description of a system, built to help us better understand the operation of a real system and the interactions of its main components. They are excellent forecast mechanisms. The popularization of computers, capable to execute great amounts of arithmetic and logical operations in a reduced time, allowed great progress in the area of mathematical simulation.

Three important uses of mathematical models in plant sciences can be indicated as the following (Rimmington \& Charles-Edwards, 1987): (i) analysis of observed responses in plant growth as a function of certain factors, to increase our understanding of the crop growth and to provide direction in our research; (ii) simulation of plant growth by models consisting of many interacting components and levels, as an aid for teaching and learning; and (iii) forecast of the plants response of to certain climatic or management condition, as a tool for management and decision-making.

\section{SCIENTIFIC IMPORTANCE OF MATHEMATICAL MODELS}

Unfortunately, many have the idea that a model can supply the knowledge one does not have about a system. As emphasized, the model is a simplified version of the system and it will be as good as the available knowledge of the system.

Is it true that only a well known system can be modeled? And if it is well known, why model it? It is evident that the objective of modeling is to produce a tool that can be used to test hypotheses, to generate alternative hypotheses, to suggest experiments, to refute them, and furthermore, to predict the behavior of the system in unknown situations.

Each researcher has his or her own image, a visualization, or a symbolism to obtain a model of the system with which he or she works. The elaboration of a model is just the formalization of his or her knowledge.

Pereira (1987) states: (i) the attempt of building a model helps to detect areas where the 
knowledge and data are scarce; (ii) the modeling process stimulates new ideas; (iii) compared with traditional methods, the models make, usually, a better use of data; (iv) models allow interpolation and prediction; (v) a model summarizes large amounts of information; (vi) a good model can be used to suggest priorities in the application of resources for research; (vii) the mathematical basis for the hypothesis allows progress in better understanding the behavior of the system and discerning among alternative hypotheses.

It can be noticed that the elaboration of a mathematical model follows exactly the basic rules of the Scientific Method, that is: (i) observation of a system; (ii) formulation of a hypothesis in the attempt of explaining the observations; (iii) prediction of the system behavior of through simulation; (iv) experimentation to test the validity of the hypothesis (validation of the model).

\section{IMPORTANCE OF THE MATHEMATICAL MODELS IN FARM MANAGEMENT AND OTHER PRACTICAL APPLICATIONS}

Besides its scientific importance, the simulation of plant yield has practical application in the management of cropping systems, in the formation of stocks, in the commercialization, in the making of agricultural policies and zoning, and in many other branches of agricultural activity.

The mathematical models used in each one of those contexts will have a different form and will be used in different ways. In a context of resource management, the models can serve as a learning aid in predicting the results of a given usual practice compared to alternative actions in the agricultural system.

The model to be used in management is a summarized form of the detailed simulation model obtained through research, in which several intermediate state variables are removed and some parameters are maintained constant for the particular case.

Before the model is applied for resource management, its accuracy needs to be tested within a given range of variables. Only then it is wise to use the model to simulate the effects of different management techniques or environmental variations on the crop performance. The model, in this case, should necessarily be used within its tested boundaries (Rimmington \& Charles-Edwards, 1987).

\section{FINAL CONSIDERATIONS}

There is no such thing as a right or wrong model, but models with variable degrees of suitability for a certain circumstance. There is no universal model that provides a solution for all problems, however models should continue to be developed and adapted to several particular situations.

The professionals working with modeling should define their objectives prior to constructing their models, and the model users should choose one that has been developed to solve their particular needs.

\section{REFERENCES}

ACOCK, B.; REDDY, V.R.; WHISLER, F.D.; BAKER, D.N.; McKINION, J.M.; HODGES, H.F.; BOOTE, K.F. The soybean crop simulator GLYCIM: model documentation. Washington: USDA, 1985.

ACOCK, B.; ACOCK, M. Potential for using long-term field research data to develop and validate crop simulators. Agronomy Journal, V.83, p.56-61, 1991.

CHANTER, D.O. The use and misuse of linear regression methods in crop modeling. In: ROSE, D.A.; CHARLES-EDWARDS, D.A. (Ed.) Mathematics and plant physiology. London: Academic Press, 1981. p.253-266.

CROWTHER, J. (Ed.) Oxford advanced learner's dictionary of current english. 5.ed. Oxford: Oxford University Press, 1995. 1430p.

JENSEN, M.E. Water consumption by Agricultural plants. In: KOSLOWSKI, T.T. Water deficits and plant growth. New York: Academic Press, 1968. v.2, cap.1, p.1-22

PEREIRA, A.R. Simulação do crescimento e da produtividade. In: SIMPÓSIO SOBRE O MANEJO DE ÁGUA NA AGRICULTURA. Anais. Campinas: Fundação Cargill, 1987. 226p.

PROCTER, P. (Ed.) Cambridge international dictionary of english. Cambridge: Cambridge University Press, 1995. 1774p.

RIMMINGTON, G.M.; CHARLES-EDWARDS, D.A. Mathematical descriptions of plant growth and development. In: WISIOL, K.; HESKETH, J.D. Plant growth modeling for resource management: current models and methods. Boca Raton: CRC Press, 1987. v.1, p.3-15. 
STEWART, J.I.; CUENCA, R.H.; PRUITT, W.O.; HAGAN, R.M.; TOSSO, J. Determination and utilization of water production functions for principal California crops. Davis: University of California, 1977. (California Contrib. Project Reports, w-67)

TERUEL, D.A. Modelagem do índice de área foliar da cana-de-açúcar em diferentes regimes hídricos. Piracicaba, 1995. 93p. Dissertação (Mestrado) Escola Superior de Agricultura "Luiz de Queiroz", Universidade de São Paulo.
WAGGONER, P.E. Agriculture and carbon dioxide. American Science, v.72, p.179-184, 1984.

WU, H.; CHILDRESS, W.M.; LI, Y.; SPENCE, R.D.; REN,J. An integrated simulation model for a semiarid agroecosystem in the Loess Plateau of Northwestern China. Agricultural Systems, v.52, p.83-111, 1996.

Recebido para publicação em 10/07/98

Aceito para publicação em 03/08/98 